\title{
Effect of floc structure and strength on membrane permeability in the hybrid coagulation-microfiltration process
}

\author{
Bingqing Zhao, Dongsheng Wang, Tao Li and Chihpin Huang
}

\section{$\overline{\text { ABSTRACT }}$}

The relative importance of floc property on microfiltration and fouling mechanism remains a field

Bingqing Zhao

Dongsheng Wang

of arguments. The effects of floc structure and strength on fouling rate of coagulation-

microfiltration were investigated in dead-end microfiltration. Flocs varying in size, fractal structure

Tao Li

State Key Laboratory of Environmental

Aquatic Chemistry,

and strength were prepared by $\mathrm{AlCl}_{3}$ and $\mathrm{PACl}$ (Polyaluminum Chloride) coagulation at various

dosages followed by different slow mixing rates and filtration without any sedimentation step.

Research Center for Eco-Environmental Sciences,

Chinese Academy of Sciences,

No. 18, Shuangqing Road,

The rates of flux decline for flocs formed under same coagulant dosage but different shear conditions showed only limited size and compactness dependence. However, the floc strength effect on membrane filtration performance was observed clearly with the floc strength constant exhibiting a strong positive linear correlation with the resulted cake compressibility index.

Haidian District

Beijing 100085,

China

E-mail: zhaobingqing@gmail.com; taoli@rcees.ac.cn

Chihpin Huang

Institute of Environmental Engineering

National Chiaotong University,

Hsinchu,

Chinese Taiwan

E-mail: cphuang@mail.nctu.edu.tw

Dongsheng Wang (corresponding author)

State Key Laboratory of Environmental

Aquatic Chemistry,

Research Center for Eco-Environmental Sciences, Chinese Academy of Sciences,

No. 18, Shuangqing Road

Haidian District,

Beijing 100085,

China,

E-mail: wgds@rcees.ac.cn

\section{NOMENCLATURE}

$\begin{array}{llll}A & \text { membrane filtration area }\left(\mathrm{m}^{2}\right) & R_{m} & \text { membrane resistance }\left(\mathrm{m}^{-1}\right) \\ d_{a} & \text { aggregate size }(\mu \mathrm{m}) & R_{t} & \text { total filtration resistance }\left(\mathrm{m}^{-1}\right) \\ d_{p} & \text { particle size }(\mu \mathrm{m}) & t & \text { filtration time }(\mathrm{s}) \\ D f & \text { fractal dimension } & \text { Greek letters } & \\ G & \text { average velocity gradient }\left(\mathrm{s}^{-1}\right) & \alpha_{0} & \text { specific cake resistance at unit pressure } \\ J & \text { permeate flux }\left(\mathrm{L} \mathrm{m}^{-2} \mathrm{~h}^{-1}\right) & & \left(\mathrm{m} \mathrm{kg}^{-1} \mathrm{~Pa}^{-1}\right) \\ m & \text { cake mass }(\mathrm{kg}) & \alpha_{c} & \text { specific cake resistance }\left(\mathrm{m} \mathrm{kg-}^{-1}\right) \\ n & \text { compressibility index } & \epsilon_{\mathrm{c}} & \text { cake porosity } \\ P & \text { transmembrane pressure }(\mathrm{kPa}) & \mu & \text { viscosity }(\mathrm{kPa}) \\ q & \text { momentum transfer } & \gamma & \text { floc strength constant } \\ R_{c} & \text { cake resistance }\left(\mathrm{m}^{-1}\right) & \rho_{p} & \text { particles density }\left(\mathrm{kg} \mathrm{m}^{-3}\right)\end{array}$




\section{INTRODUCTION}

Combined coagulation and membrane filtration has become an attractive alternative of conventional water treatment to increase the removal of natural organic matter (Judd \& Hillis 200I), improve membrane flux and even mitigate irreversible membrane fouling (Kimura et al. 2005). The hybrid coagulation-microfiltration process such as submerged membrane systems or direct membrane filtration processes which do not require to include settling processes are becoming more popular in the water industry (Choi et al. 2008). There is also a tendency to use dead-end MF or UF systems rather than pumped cross-flow systems to reduce energy consumption (Lee et al. 2005). However, membrane fouling in dead-end mode has been known as the major problem. Research effort to overcome this issue in hybrid membrane process is far from being enough.

For dead-end membrane filtration of coagulated suspension, the flux of permeate through the membrane $(J)$ can be described as a resistance-in-series model

$J=\frac{\Delta P}{\mu R_{t}}=\frac{\Delta P}{\mu\left(R_{m}+R_{c}\right)}$

where the $J$ is the water flux; $\mu$ the viscosity of water; $\Delta P$ the trans-membrane pressure (TMP); $R_{m}$ is the membrane resistance and $R_{c}$ the cake resistance.

The cake resistance $\left(R_{c}\right)$ is proportional to the solid cake mass deposited on the membrane (m) per unite area of the effective membrane surface and the specific cake resistance $\left(\alpha_{c}\right)$ :

$R_{c}=\alpha_{c} \frac{m}{A}$

In dead-end filtration of flocs, the cake resistance tends to dominate so that the filtration depends on the specific cake resistance, which in turn depends on the floc structure. Floc characteristics, such as floc size, floc strength, fractal dimension, play an important role in reducing membrane fouling in the coagulation-membrane filtration hybrid process. There is a great amount of literature to support the importance of floc properties in coagulation-MF or UF hybrid process. For rigid spheres the well-know Carman-Kozeny equation which relates the specific resistance $\left(\alpha_{c}\right)$ to particle size $(d p)$ and cake porosity $\left(\epsilon_{c}\right)$ has been widely recognized in early research.

$\alpha_{c}=\frac{180\left(1-\epsilon_{c}\right)}{\rho_{p} d_{p}^{2} \epsilon_{c}^{3}}$

While for flocculated aggregates, the structural character can be related to the fractal dimension as reported that the aggregates porosity $\left(\epsilon_{a}\right)$ is related to the primary particle size $\left(d_{p}\right)$, the aggregate size $\left(d_{a}\right)$ and the fractal dimension by (Veerapaneni \& Wiesner 1996)

$\epsilon_{a}=1-\left(\frac{d_{a}}{d_{p}}\right)^{d F-3}$

Guan \& coworkers (200I) first described a modified Carman-Kozeny relationship which related the specific resistance with both floc size and fractal Equation (5)

$\alpha_{c} \propto \frac{1}{\left(d_{a} / d_{p}\right)^{3-d F} \times\left(1-\left(d_{a} / d_{p}\right)^{d F-3}\right)^{3}}$

As indicated by the modified Carman-Kozeny relationship, specific resistance would increase with decreasing floc size and increasing fractal dimension if the fractal and size nature of the floc is preserved in the filtration (Lee et al. 2005).

For compressible cake layer, the cake compressibility can be described using a power law of the specific cake resistance $\left(\alpha_{c}\right)$ as a function of trans-membrane pressure $(\Delta P)$

$\alpha_{c}=\alpha_{0} \Delta P^{n}$

where $\alpha_{0}$ is the specific cake resistance at unit pressure and $n$ is the compressibility index. The slope of linear fits of log plots of $\alpha_{\mathrm{c}}$ at various $\Delta P$ gives the value of $n$.

Many studies have addressed consistent results. Lee $e t$ al. (2003) investigated the effect of floc size and structure on specific cake resistance and compressibility in dead-end microfiltration. They concluded that larger flocs produced filter cakes of lower specific resistance and floc structure effects were more significant for smaller floc, with higher specific resistance for cakes formed from more compact flocs. Cho et al. (2005) reported that coagulated flocs of lower fractal dimension can improve membrane permeability due to its higher porosity and relatively loose aggregation. 
Until recently, reports began to highlight the importance of floc strength or the floc resistibility to shear stress. Choi et al. (2008) reported flocs of high humic water, with small size and regular in shape represented by the low flocculation index (FI) and high fractal dimension, have higher specific cake resistance and can be more compressible than those of low humic natural water. Barbot et al. (2008) reported that better capacity of flocs resistant to shear stress improved the permeate flux.

The objective of this study was to develop a further fundamental understanding of the effects of floc properties of size, fractal structure and strength on membrane fouling in hybrid coagulation-microfiltration process. Flocs of different characteristics were prepared by coagulation of kaolin particles and humic acid synthetic water with aluminum-based coagulant followed by dead-end microfiltration without any sedimentation process. Their flux behaviors were compared to provide deep insights into effect of floc characteristics on membrane permeability. The importance of floc strength was discussed in conjunction with cake compressibility.

\section{$\overline{\text { METHODS }}$}

\section{Synthetic water}

The humic acid stock solution was prepared by dissolving $4 \mathrm{~g}$ of HA (Tianjin, China) into $500 \mathrm{~mL} 0.01 \mathrm{~mol} / \mathrm{L} \mathrm{NaOH}$ solution. Then, the solution was stirred for $24 \mathrm{~h}$, and filtered through a $0.45 \mu \mathrm{m}$ membrane to remove residual non-dissolved humic acid. Dissolved organic carbon (DOC) of the stock solution was measured before use (TOC-Vcph, Shimadzu, Japan).

Kaolin was applied as model particles of the synthetic water. The stock suspension of kaolin was prepared in deionized water. The solid concentration of suspension was determined by gravimetrically to be $32 \mathrm{~g} / \mathrm{L}$. The average size of the particles in suspension was close to $2.6 \mu \mathrm{m}$, measured by a laser diffraction instrument (Mastersizer 2000, Malvern, UK).

The synthetic water was prepared by dissolving the HA stock solution and kaolin stock suspension in deionized water with $0.001 \mathrm{~mol} / \mathrm{L} \mathrm{NaHCO}_{3}$ to provide ionic strength and $\mathrm{pH}$ buffers. A summary of the synthetic water quality characteristics is shown in Table $1 . \mathrm{UV}_{254}$ was measured by a spectrophotometer (UV-Vis 8500, China) using a $1 \mathrm{~cm}$ quartz cell after filtration through $0.45 \mu \mathrm{m}$ membrane. The turbidity was measured by a turbidimeter (Hach 2100P Turbidimeter, USA). The zeta potentials were evaluated using a zeta meter (Zetasizer, Malvern, UK).

\section{Pre-coagulation experiment}

$\mathrm{AlCl}_{3}$ (Beijing Chemical Regent Company, China) and a commercial product of PACl (Wanshui Water Cleaning Agent Co., China) were used as coagulant. Coagulation was performed on a programmable jar test apparatus (Daiyuan Jar Test instruments, China) to prepare various flocs. The impeller type is $4 \mathrm{~cm} \times 5 \mathrm{~cm}$ flat blade. Specifically, the procedures are as follows: the sample water was first mixed rapidly at $250 \mathrm{rpm}$ for $30 \mathrm{~s}$. Then the coagulant was dosed by pipettes followed by a rapid mixing at $200 \mathrm{rpm}$ for $1 \mathrm{~min}$ and a slow mixing at 40, 100, 150 and $200 \mathrm{rpm}$ for $15 \mathrm{~min}$, respectively. The rotary speed (rpm) and its corresponding $G$ value $\left(\mathrm{s}^{-1}\right)$ which was automatic calculated and shown by the jar tester were listed in Table 2. In pre-coagulation jar test, slow mixing rate of $40 \mathrm{rpm}$ was used and a sample of supernatant water was taken for water quality analysis after $20 \mathrm{~min}$ sedimentation.

Floc size and breakage experiment were performed using the experimental setup similar to those of Jarvis et al. $(2005 c)$. In floc breakage experiment, coagulation tests were performed as pre-coagulation jar test; however, after the slow stir phase, increased shear for rpm of 40, 100, 150 and 200 were investigated for a further $15 \mathrm{~min}$. Dynamic floc size was monitored during growth and breakage using Small angle

Table 1 Characteristics of synthetic water

\begin{tabular}{|c|c|c|c|c|c|c|}
\hline pH & DOC (mg/L) & $\mathbf{U V}_{254}$ & Kaolin concentration (mg/L) & $\mathrm{NaHCO}_{3}$ concentration (mol/L) & Zeta potential (mV) & Turbidity (NTU) \\
\hline $7.8 \sim 7.9$ & $3.0 \sim 3.13$ & $0.396 \sim 0.400$ & 50 & 0.001 & $-30.0 \sim-32.4$ & $61-62$ \\
\hline
\end{tabular}


Table 2 | The rotary speed (rpm) and its corresponding $G$ value $\left(\mathrm{s}^{-1}\right)$

\begin{tabular}{ll} 
Rotary speed $(\mathbf{r p m})$ & $\boldsymbol{G}$ value $\left.\mathbf{( s}^{-\mathbf{1}}\right)$ \\
\hline 40 & 11.5 \\
100 & 39.3 \\
150 & 67.7 \\
200 & 99.7 \\
\hline
\end{tabular}

laser light scattering methods SALLS (Mastersizer 2000, Malvern, UK). The median equivalent volumetric diameter $\left(d_{50}\right)$ was used to indicate the average floc size and the size measurements were taken every $40 \mathrm{~s}$ for the duration of the jar test and logged onto a PC. Floc properties such as fractal dimension and floc strength were calculated using the above floc size data.

\section{Microfiltration experiment}

A schematic diagram of the dead-end MF system used in this study is shown in Figure 1. Microfiltration began immediately at the end of slow stir phase of coagulation. And the floc suspension was stirred continuously with their original slow mixing intensity of 40,100,150 and $200 \mathrm{rpm}$ respectively at the same time. The floc was sucked into the membrane cell by a vacuum pump (GAST, USA) to avoid any further floc breakage. A constant TMP of $50 \mathrm{kPa}$ was supplied by the vacuum pump which was adjusted carefully to a set value by the regulator. A fresh piece of membrane was used in all the experiment. The flat sheet membrane was fixed in the membrane holder which connected to a $1 \mathrm{~L}$ tank for permeate collection. Permeate mass was weighted by an electronic balance (PL2002-IC, Mettler-Toledo, Switzerland) and recorded via a computer equipped with a data acquisition system at a predetermined time interval. The room temperature was maintained at $20^{\circ} \mathrm{C}$. The filtration was terminated when the accumulated permeate volume reached $250 \mathrm{ml}$.

The measurement of compressibility index was carried out in an unstirred cell unit and slow mixing intensity of $40 \mathrm{rpm}$ was used for floc preparation. After the jar test, each coagulated solution was gently transferred into the feed tank and agitated to make a uniform suspension of the coagulated flocs prior to the unstirred dead-end MF. TMP was changed from 20 to $80 \mathrm{kPa}$ for these compression-permeability experiments.

The MF membrane used in this study was PVDF flat sheet membrane with an average pore size of $0.22 \mu \mathrm{m}$ (DURAPORE $^{\circledR}$ membrane filters, Millipore). The membrane was soaked in deionized water at least $24 \mathrm{~h}$ before use and the clean water flux was measured before floc filtration.

\section{RESULTS AND DISCUSSION}

\section{Pre-coagulation}

The variations of residual turbidity and zeta potential as the function of coagulant dosages $(0.04-0.16 \mathrm{mmol} / \mathrm{L}$ as $\mathrm{Al})$ were shown in Figure 2. It could be seen that the zeta potential changed from negative to positive with the increase of coagulant dosage. The zeta potentials of PACl coagulation was slightly higher than $\mathrm{AlCl}_{3}$ application because higher $\mathrm{Alb}$ species in $\mathrm{PACl}$ resulting better charge neutralization capacity (Wang \& Tang 2006). The dosages of 0.08, 0.12,

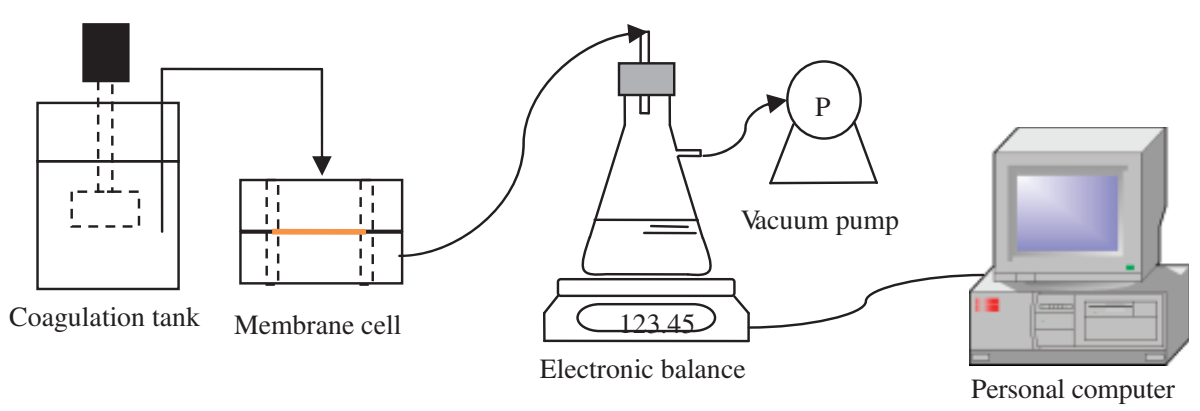

Figure 1 | Schematic of experimental setup for coagulation-microfiltration hybrid process. 


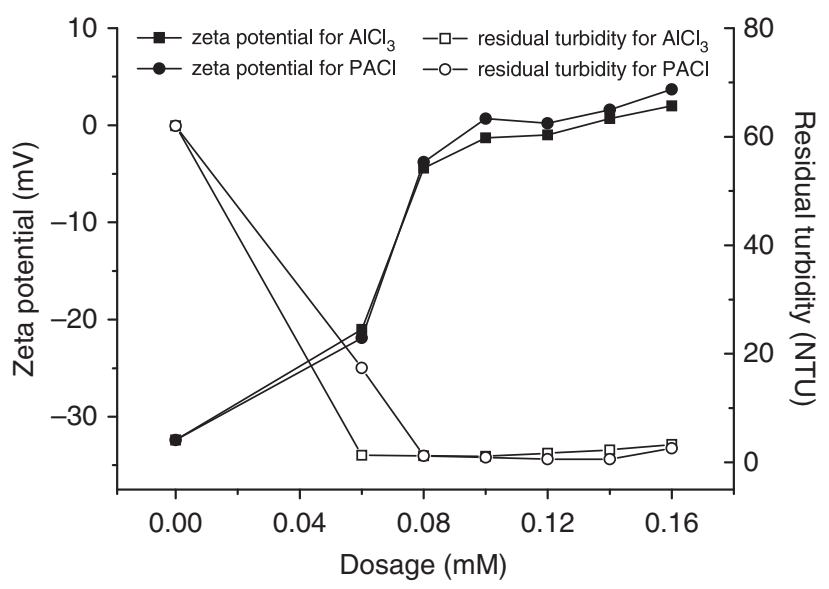

Figure 2 Coagulation performances varying with $\mathrm{AlCl}_{3}$ and $\mathrm{PACl}$ dosage.

$0.16 \mathrm{mmol} / \mathrm{L}$ for $\mathrm{AlCl}_{3}$ and $0.08,0.16 \mathrm{mmol} / \mathrm{L}$ for $\mathrm{PACl}$ were chosen for floc preparation as well as the subsequent microfiltration investigation.

\section{Floc characterization}

Detailed structural analysis of flocs determined by SALLS method has been widely reported using Mastersizer 2000 (Jarvis et al. 2005a; Li et al. 2006; Wang et al. 2008; Wang et al. 2009). In the present study, the floc size was first monitored and the floc compaction was further calculated by fractal dimension analysis which is described by the following relationship between the measured scattered intensity of aggregate clusters (I(q)) and the momentum transfer (q) (Equation (7).

$I(q) \propto \mathrm{q}^{-D f}$

When the light intensity is plotted versus the wave vector on a log-log scale, the fractal dimension is calculated in the linear region by linear regression with the R-square all more than 0.99 in this study.

Table 3 shows the detailed stabilized floc sizes and fractal dimensions at various coagulation conditions. It could be noticed that the fractal dimensions were in the range of 2.45-2.75 being proportional to hydraulic gradient and floc sizes were inversely proportional to the hydraulic gradient. This was because the shear force intensity dominated the floc
Table 3 | Stabilized floc size and fractal dimension for each coagulation

\begin{tabular}{|c|c|c|c|}
\hline Coagulant & G value $\left(s^{-1}\right)$ & $\begin{array}{l}\text { Steady state } \\
\text { size, } \mathbf{d}_{\mathbf{5 0}}(\mu \mathbf{m})\end{array}$ & $\begin{array}{l}\text { Fractal } \\
\text { dimension, Df }\end{array}$ \\
\hline \multirow[t]{4}{*}{$\mathrm{AlCl}_{3}-0.08 \mathrm{mmol} / \mathrm{L}$} & 11.5 & 308 & 2.56 \\
\hline & 39.3 & 166 & 2.60 \\
\hline & 67.7 & 120 & 2.65 \\
\hline & 99.7 & 83 & 2.71 \\
\hline \multirow[t]{4}{*}{$\mathrm{AlCl}_{3}-0.12 \mathrm{mmol} / \mathrm{L}$} & 11.5 & 439 & 2.51 \\
\hline & 39.3 & 160 & 2.59 \\
\hline & 67.7 & 95 & 2.63 \\
\hline & 99.7 & 87 & 2.69 \\
\hline \multirow[t]{4}{*}{$\mathrm{AlCl}_{3}-0.16 \mathrm{mmol} / \mathrm{L}$} & 11.5 & 598 & 2.68 \\
\hline & 39.3 & 269 & 2.70 \\
\hline & 67.7 & 188 & 2.71 \\
\hline & 99.7 & 136 & 2.72 \\
\hline \multirow[t]{4}{*}{$\mathrm{PACl}-0.08 \mathrm{mmol} / \mathrm{L}$} & 11.5 & 331 & 2.44 \\
\hline & 39.3 & 136 & 2.57 \\
\hline & 67.7 & 92 & 2.62 \\
\hline & 99.7 & 71 & 2.66 \\
\hline \multirow[t]{4}{*}{$\mathrm{PACl}-0.16 \mathrm{mmol} / \mathrm{L}$} & 11.5 & 502 & 2.64 \\
\hline & 39.3 & 256 & 2.66 \\
\hline & 67.7 & 162 & 2.67 \\
\hline & 99.7 & 117 & 2.68 \\
\hline
\end{tabular}

size and fractal dimensions (Li et al. 2006). The current understanding suggests that flocs become more compact upon exposure to shear increases as they break at their weak points and rearrange into smaller and more stable structures (Selomulya et al. 200I; Jarvis et al. 2005b). Therefore, as the shear of low intensity was introduced, the floc formed with more open structure with lower fractal dimension, while at high shear intensity denser flocs with higher fractal dimensions were produced. While with dose increment, flocs are made up of more aluminum hydroxide precipitates, which are more compact and less porous structure (Lee et al. 2000).

The shear-based floc strength and breakage models were employed in floc strength characterization in this study. Specifically, when the floc size after $15 \mathrm{~min}$ exposure to shear was plotted against $G$ value, a straight line could be drawn through the data on a log-log scale (Figure 3). Based on an empirical expression about the relationship between stable floc size and the applied shear (Equation (8)), the $\gamma$ 


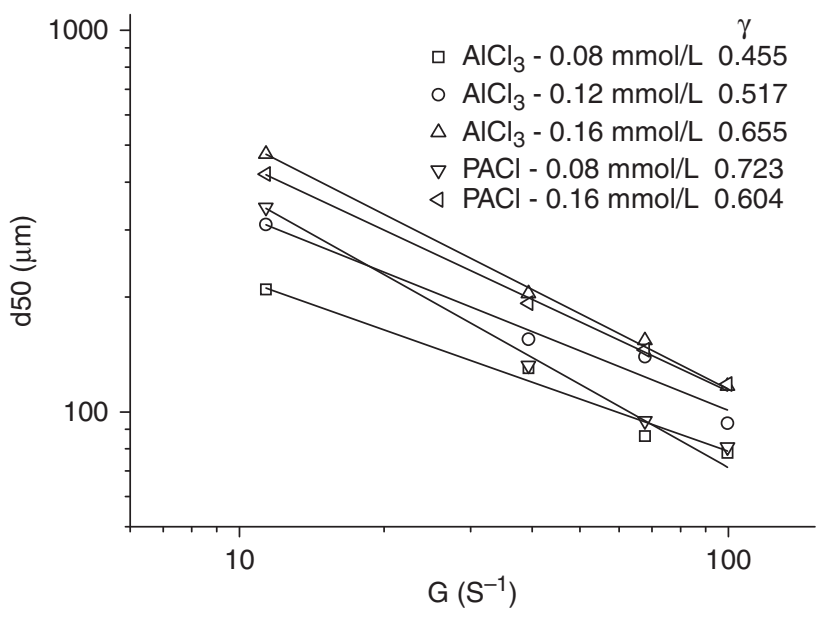

Figure 3 The log-log curve of floc size and $G$ values $\left(R^{2}>0.98\right)$.

value (the floc strength constant) is considered as an indicator of floc strength (Jarvis et al. 2005a).

$\log \mathrm{d}=\log \mathrm{C}-\gamma \log \mathrm{G}$

For $\mathrm{AlCl}_{3}$, floc strength constant increased with the dosage increment, while in the case of $\mathrm{PACl}$, the constant for dosage of 0.08 were larger than that of $0.16 \mathrm{mmol} / \mathrm{L}$ as $\mathrm{Al}$. It has been identified that a steeper slope is indicative of flocs that are less able to withstand changes in hydrodynamic shear (Li et al. 2006). Thus, it was proposed that flocs tend to be weaker with dosage increasing for $\mathrm{AlCl}_{3}$, while for $\mathrm{PACl}$, flocs of dosage $0.08 \mathrm{mmol} / \mathrm{L}$ were weaker than that of $0.16 \mathrm{mmol} / \mathrm{L}$.

Floc characteristic results as described above agree with previous works which demonstrate a definite change in floc properties with changes of dosage (Kim et al. 200I; Jarvis et al. 2005c; Wang et al. 2008). As for floc strength, a general trend has been concluded by Jarvis et al. (2005a) that floc strength decreased with increasing floc size. However, the PACl application was contrary to this general conception. The $\mathrm{Al}$ speciation characteristics should be employed to better understand this phenomenon. Floc strength is dependent upon the interparticle bonds between the components of aggregate (Jarvis et al. 2005a). As reported by Hiradate \& Yamaguchi (2003), the $\mathrm{Al}_{\mathrm{a}}-\mathrm{HA}$ is much more stable than $\mathrm{Al}_{13}-\mathrm{HA}$ complex. $\mathrm{Al}_{13}$-HA complexe was decomposed into $\mathrm{Al}_{\mathrm{a}}$-HA complexe with reaction time. Since a relative large portion of $\mathrm{Al}$ in $\mathrm{PACl}$ presented as $\mathrm{Al}_{\mathrm{b}}$ and $\mathrm{Al}_{\mathrm{c}}$ (no reaction species), the floc strength of $\mathrm{AlCl}_{3}$-floc must be better than that of PACl-floc. Therefore, with dose increment for $\mathrm{PACl}$, the amount of stable $\mathrm{Al}_{\mathrm{a}}-\mathrm{HA}$ complex increase and the floc strength is also improved. These reasons described above are also partly the reason of fractal difference between $\mathrm{AlCl}_{3}$ and $\mathrm{PACl}$.

\section{Membrane permeability in coagulation-MF}

Since the size changed with shear conditions (Table 3), it was presumed that the filterability of flocs would also be changed accordingly. Therefore, the permeate flux of floc formed with the same dosage but different shear conditions were compared. However, the rates of flux decline for flocs formed under various shear conditions with the same coagulant dosage did not show a strong size-dependence (Table 4). Although according to modified Carman-Kozeny equation, the cake layer consisting of larger and looser flocs may result in larger porosity and higher permeability (Guan et al. 200I), the result shown in Table 4 suggests that the floc size and compactness have only limited effect on permeability.

Likewise, by comparing the flux declines of floc prepared with different coagulant dosages (Figure 4 for instance), it could be found that larger or looser flocs do not always result in better water permeability. Moreover, although the cake resistance was not affected only by floc structure but also by the solid concentration of the floc suspension (Wang et al. 2008), the cake mass did not show much difference among them. The specific cake resistance shown in Figure 5 also suggests that even the solid concentration is slightly higher at overdose, it is not sufficient to explain the significant difference between fouling rates of various flocs. Additionally, the apparent trend that stronger flocs provide better water permeability should be highlighted; even there is an exception

Table 4 | Flux decline (\%) of various flocs

\begin{tabular}{|c|c|c|c|c|}
\hline \multirow[b]{2}{*}{ Coagulant } & \multicolumn{4}{|c|}{$\begin{array}{l}\text { Flux at end of test, } \mathrm{J} / J_{0}(\%) \text { for floc formed under } \\
\text { various } \mathrm{G} \text { value }\end{array}$} \\
\hline & $11.5 \mathrm{~s}^{-1}$ & $39.3 \mathrm{~s}^{-1}$ & $67.7 \mathrm{~s}^{-1}$ & $99.7 \mathrm{~s}^{-1}$ \\
\hline $\mathrm{ACl}_{3}-0.08 \mathrm{mmol} / \mathrm{L}$ & 38.2 & 35.4 & 33.2 & 31.7 \\
\hline $\mathrm{ACl}_{3}-0.12 \mathrm{mmol} / \mathrm{L}$ & 33.7 & 33.3 & 34.8 & 32.3 \\
\hline $\mathrm{ACl}_{3}-0.16 \mathrm{mmol} / \mathrm{L}$ & 25.2 & 28.2 & 26.2 & 29.4 \\
\hline $\mathrm{PACl}-0.08 \mathrm{mmol} / \mathrm{L}$ & 19.4 & 17.8 & 14.1 & 19.1 \\
\hline $\mathrm{PACl}-0.16 \mathrm{mmol} / \mathrm{L}$ & 24.1 & 23.1 & 22.4 & 20.5 \\
\hline
\end{tabular}




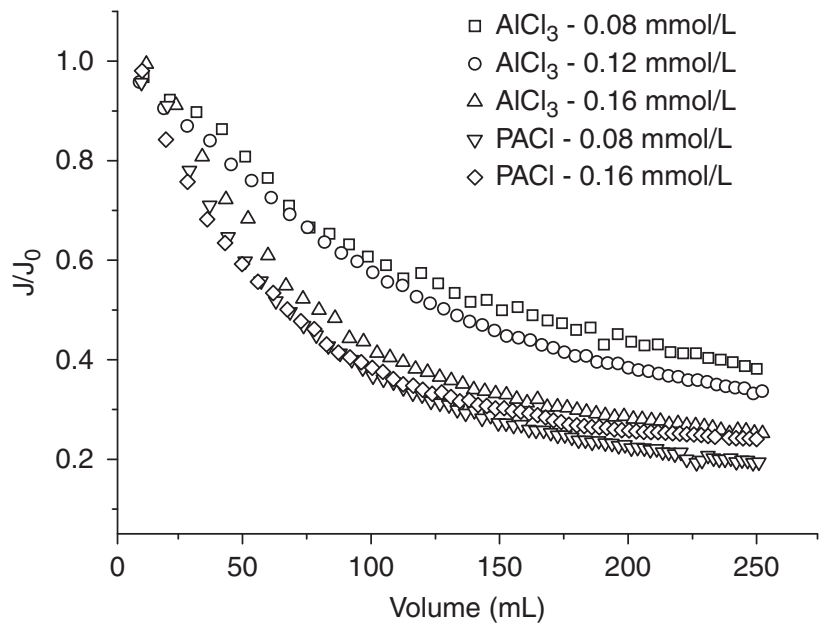

Figure 4 Comparison of flux profiles for various flocs $\left(\mathrm{G}=11.5 \mathrm{~s}^{-1}\right)$.

for floc comparison of $\mathrm{AlCl}_{3}-0.16 \mathrm{mmol} / \mathrm{L}$ with $\mathrm{PACl}-$ $0.16 \mathrm{mmol} / \mathrm{L}$ which might due to the difference in the chemistry of coagulation between them.

Four reasons can explain the discrepancy of the results with the general understanding of the effect of floc size on filtration performance. First, it should be noted that the conventional Carman-Kozeny equation and modified CarmanKozeny relationship are only suitable for rigid sphere or situation of which nature of aggregates can be preserved in the filtration process. The cakes formed with humic flocs are very compressible. Therefore, the compression may, to some extent, obscure the effect of floc size and compactness on the membrane fouling rate and the specific cake resistance.

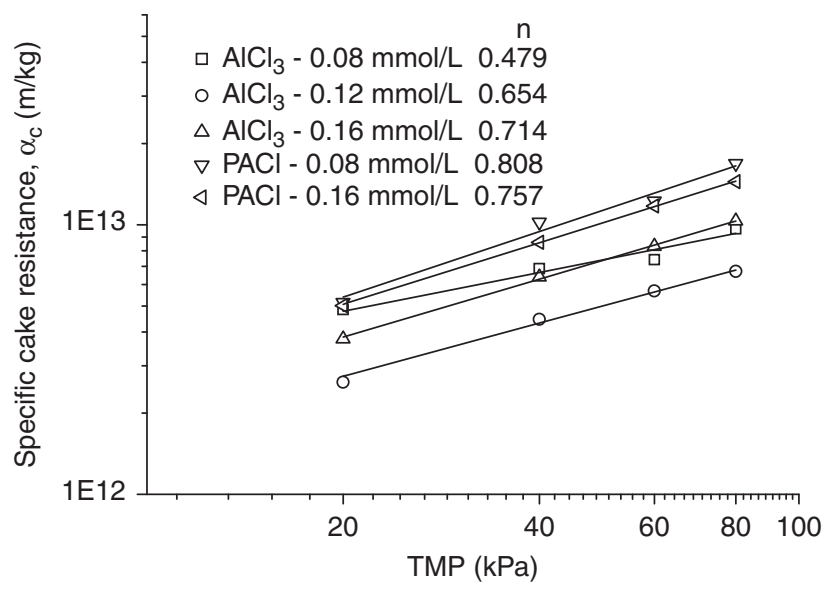

Figure 5 | Variations of specific cake resistance with TMP at different coagulation dosages.
Besides, previous works' analyses on floc size and structure effect in membrane filtration were based on floc prepared by different coagulant dosages (Guan et al. 200I). However, different coagulant dose with same coagulation condition generally lead to changes in floc size, fractal and strength properties simultaneously, making it difficult to separate the size effect from the fractal effect.

Furthermore, although being an important factor influencing the floc compressibility, the floc strength has been neglected for a long time in studies of floc structure effect on membrane filtration performance. However, just as Barbot et al. (2008) have identified, the size is not sufficient to explain membrane performance, the floc must be large and coupled with higher resistance capacity to facilitate flow between aggregates.

Finally, the range of floc size investigated might be another reason. Lee et al. (2003) have addressed that the dependence of cake permeability on the fractal dimension was negligible for cake composed of aggregates larger than about $40 \mu \mathrm{m}$. Large floc may not exhibit the same cake resistance response to floc size and fractal changes, especially for very compressible floc or cake.

\section{Cake compressibility and floc strength}

Cake compressibility was evaluated through an unstirred batch cell test and the compressibility index was determined from the regression analyses of sample data indicated by the

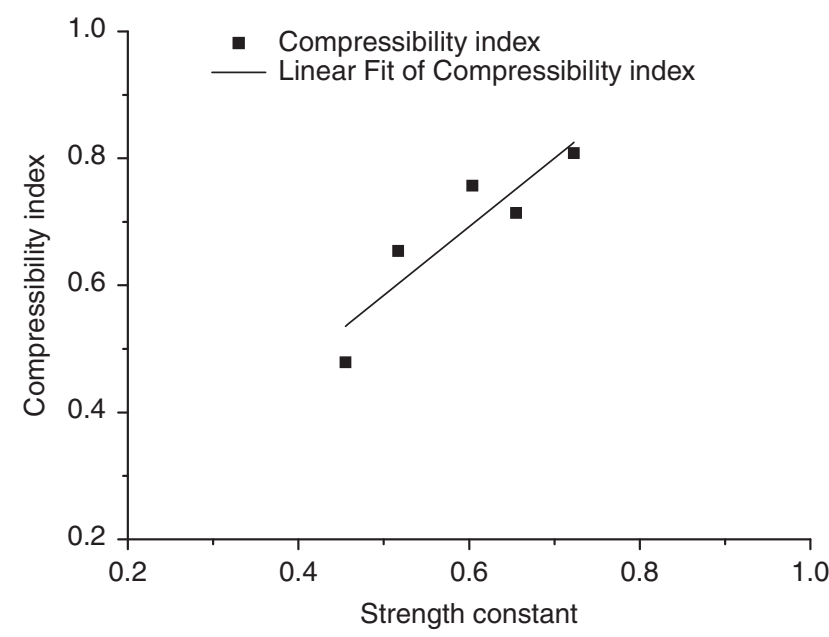

Figure 6 The regression analysis of the cake compressibility index and the floc strength constant. 
slope of the straight line (Figure 5). The flocs were both very compressible with cake compressibility index in the range of 0.47 to 0.81 . The stronger flocs tend to have lower specific cake resistance at high TMP although there was a little argument for Ala- $0.12 \mathrm{mmol} / \mathrm{L}$.

It was proposed that there is a positive linear correlation between the cake compressibility index and the floc strength constant. The regression analysis was carried out and shown in Figure 6. The square of the correlation coefficient is 0.83 . It highlights a strong relationship between the cake compressibility and the floc strength.

Although the general understanding that larger and looser flocs have better filterability have been widely accepted (Guan et al. 200I), an important issue still relates to the extent to which the structure character of flocs is maintained in the filter cake. Analogous to changes in aggregate morphology during coagulation, the applied pressure itself can be expected to induce cake rearrangement and compression with greater rearrangement expected at higher applied pressures (Xu et al. 2004; Lee et al. 2005). From this viewpoint, the floc size changes in accord with the applied shear rates during the floc strength measurement might be expected to be analogous to the cake rearrangement induced by applied pressure in the cake compressibility analysis. The floc strength constant thus could be expected to have strong relationship with the cake compressibility as verified in the present study.

\section{CONCLUSIONS}

The rates of flux decline for flocs formed under same coagulant dosage but different shear conditions showed limited size and compactness dependence. The compressibility of flocs may obscure the size and compactness effect on water permeability for direct microfiltration of flocs suspension. However, the floc strength effect on membrane filtration performance was observed clearly with the floc strength constant exhibiting a strong positive linear correlation with the resulted cake compressibility index. The most important factor influencing the membrane performance for highly compressible flocs in dead end microfiltration is the coagulant dosage via its effect on floc structure, especially the floc strength.

\section{$\overline{\text { ACKNOWLEDGEMENTS }}$}

This work is supported by the NSF of China under 50908224, 50921064, the national 863 program under 2008AA06A414 and the special fund from the State Key Laboratory of Environmental Aquatic Chemistry (Project 08Y03ESPCR). The kind comments from anonymous reviewers are gratefully acknowledged.

\section{$\overline{\text { REFERENCES }}$}

Barbot, E., Moustier, S., Bottero, J. Y. \& Moulin, P. 2008 Coagulation and ultrafiltration: Understanding of the key parameters of the hybrid process. Journal of Membrane Science 325(2), 520-527.

Cho, M. H., Lee, C. H. \& Lee, S. 2005 Influence of floc structure on membrane permeability in the coagulation-MF process. Water Science and Technology 51(6-7), 143-150.

Choi, Y. H., Kim, H. S. \& Kweon, J. H. 2008 Role of hydrophobic natural organic matter flocs on the fouling in coagulation-membrane processes. Separation and Purification Technology 62(3), 529-534.

Guan, J., Amal, R. \& Waite, T. 200I Effect of aggregate size and structure on specific resistance of biosolids filter cakes. Water Science and Technology 44(10), 215-220.

Hiradate, S. \& Yamaguchi, N. U. 2003 Chemical species of $\mathrm{Al}$ reacting with soil humic acids. Journal of Inorganic Biochemistry 97(1), 26-31.

Jarvis, P., Jefferson, B., Gregory, J. \& Parsons, S. A. 2005a A review of floc strength and breakage. Water Research 39(14), 3121-3137.

Jarvis, P., Jefferson, B. \& Parsons, S. A. 2005b Breakage, Regrowth, and Fractal Nature of Natural Organic Matter Flocs. Environmental Science and Technology 39(7), 2307-2314.

Jarvis, P., Jefferson, B. \& Parsons, S. A. 2005c How the Natural Organic Matter to Coagulant Ratio Impacts on Floc Structural Properties. Environmental Science and Technology 39(22), 8919-8924.

Judd, S. J. \& Hillis, P. 200I Optimisation of combined coagulation and microfiltration for water treatment. Water Research 35(12), 2895-2904.

Kim, S. H., Moon, B. H. \& Lee, H. I. 2oor Effects of pH and dosage on pollutant removal and floc structure during coagulation. Microchemical Journal 68(2-3), 197-203.

Kimura, K., Hane, Y. \& Watanabe, Y. 2005 Effect of pre-coagulation on mitigating irreversible fouling during ultrafiltration of a surface water. Water Science and Technology 51(6-7), 93-100.

Lee, J. D., Lee, S. H., Jo, M. H., Park, P. K., Lee, C. H. \& Kwak, J. W. 2000 Effect of Coagulation Conditions on Membrane Filtration Characteristics in Coagulation-Microfiltration Process for Water Treatment. Environmental Science and Technology 34(17), 3780-3788.

Lee, S. A., Fane, A. G., Amal, R. \& Waite, T. D. 2003 The effect of floc size and structure on specific cake resistance and compressibility 
in dead-end microfiltration. Separation Science and Technology 38(4), 869-887.

Lee, S. Y. A., Fane, A. G. \& Waite, T. D. 2005 Impact of natural organic matter on floc size and structure effects in membrane filtration. Environmental Science and Technology 39(17), 6477-6486.

Li, T., Zhu, Z., Wang, D., Yao, C. \& Tang, H. 2006 Characterization of floc size, strength and structure under various coagulation mechanisms. Powder Technology 168(2), 104-110.

Selomulya, C., Amal, R., Bushell, G. \& Waite, T. D. 20or Evidence of shear rate dependence on restructuring and breakup of latex aggregates. Journal of Colloid and Interface Science 236(1), 67-77.

Veerapaneni, S. \& Wiesner, M. R. I996 Hydrodynamics of fractal aggregates with radially varying permeability. Journal of Colloid and Interface Science 177, 45-57.
Wang, D. S. \& Tang, H. X. 2006 Quantitative model of coagulation with inorganic polymer flocculant PACl: application of the PCNM. Journal of Environmental Engineering 132(5), 434-441.

Wang, J., Guan, J., Santiwong, S. R. \& Waite, T. D. 2008 Characterization of floc size and structure under different monomer and polymer coagulants on microfiltration membrane fouling. Journal of Membrane Science 321(2), 132-138.

Wang, Y., Gao, B. Y., Xu, X. M., Xu, W. Y. \& Xu, G. -Y. 2009 Characterization of floc size, strength and structure in various aluminum coagulants treatment. Journal of Colloid and Interface Science 332(2), 354-359.

Xu, W., Chellam, S. \& Clifford, D. A. 2004 Indirect evidence for deposit rearrangement during dead-end microfiltration of iron coagulated suspensions. Journal of Membrane Science 239(2), 243-254. 